\title{
Optimization of performance parameters of digger for carrot crop at farmers field
}

\section{Narender and Vijaya Rani}

Received : 23.07.2019; Revised : 22.08.2019; Accepted : 09.09.2019

See end of the Paper for authors' affiliation

Correspondence to :

Narender

Department of Farm

Machinery and Power

Engineering, College of

Agricultural Engineering and

Technology, C.C.S. Haryana

Agricultural University, Hisar

(Haryana) India

Email : narender4ever@

gmail.com
-ABSTRACT : In India, the carrot crop was digged manually and it required high labour and time for digging. Keeping in view, the performance of a tractor operated digger was evaluated at farmers field for the carrot crop. The digger was evaluated at forward speeds of 2.2, 2.7 and $3.2 \mathrm{~km} \mathrm{~h}^{-1}$ and changing the rake angles of blade as $17^{\circ}, 20^{\circ}$ and $23^{\circ}$. The performance parameters viz., exposed, undug, cut, bruised percentage and the digging efficiency was evaluated as per the experiment. The performance of the digger for diging of carrot crop was found to be best at a speed of $2.2 \mathrm{~km} /$ $\mathrm{hr}$ and blade angle of 23 degree with a digging efficiency of 100 per cent, cut percentage of 46, bruised percentage of 2.28 and exposed percentage of 92.12. The field capacity of the machine was $0.18 \mathrm{ha} / \mathrm{h}$. The saving of digger as compared to manual digging was Rs. 7359 per hectare.

- KEY WORDS : Carrot, Performance, Digger, Saving, Angles

-HOW TO CITE THIS PAPER : Narender and Rani, Vijaya (2019).Optimization of performance parameters of digger for carrot crop at farmers field. Internat. J. Agric. Engg., 12(2) : 217-222, DOI: 10.15740/HAS/IJAE/12.2/217-222. Copyright@2019: Hind Agri-Horticultural Society. 